\title{
症例報告
}

\author{
腹腔鏡下に修復した腹腔鏡下術後再発鼠径へルニアの 2 例 \\ 若林 正和 河野 悟 木村 友洋佐々木一憲 \\ 藤平 大介 小池 卓也 船津健太郎 原 英則 \\ 保刈 岳雄 相崎 一雄 \\ 相模原協同病院消化器病センター外科
}

\section{Two Cases of Laparoscopic Surgery for Recurrent Inguinal Hernia after Transabdominal Preperitoneal Repair}

Masakazu WaKabayashi, Satoru Kono, Tomohiro Kimura, Kazunori Sasaki,

Daisuke Fujinira, Takuya KoIKe, Kentaro Funatsu, Hidenori Hara,

Takeo HoKari and Kazuo AISAKI

Department of Surgery, Sagamihara Kyodo Hospital

\begin{abstract}
Herein, we report 2 cases of laparoscopic surgery for recurrent inguinal hernia after transabdominal preperitoneal repair (TAPP). It is not easy to enrich laparoscopic operative skill of TAPP earlier. However, TAPP enables the evaluation of potential recurrence, to accurately diagnose the type of hernia, and simultaneous repair of the hernia orifice.
\end{abstract}

Key words: recurrent inguinal hernia, transabdominal preperitoneal repair 再発鼠径ヘルニア，腹腔鏡下ヘルニア修復術

(J. Nihon Univ. Med. Ass., 2016; 75 (5): 237-240)

要旨 腹腔鏡下ヘルニア修復術（transabdominal preperitoneal repair: 以下, TAPP) 後の再発鼠径ヘルニア に対し，再度 TAPPを施行した 2 例を経験した。 TAPP は手技の習熟は必要であるものの，腹腔鏡による観察を 活かした再発形式の評価や確実な診断および修復が可能 であると考えられた

\section{はじめに}

成人の再発鼠径ヘルニアに対する修復術としては鼠径 部切開法が一般的に普及しているが，近年では腹腔鏡下 修復術の有用性を支持する報告も散見される ${ }^{1 \sim 4)}$ 。鼠径 ヘルニアに対する腹腔鏡下手術の普及が進む一方で，日 本内視鏡外科学会のアンケート調査では, TAPP の再発 率は $4 \%$ であり ${ }^{5)}$, 今後 TAPP 後の再発症例が増える可 能性もあるが，TAPP 後に再度 TAPPを施行した詳細な 報告は少ない。今回われわれは，TAPP 後の再発鼠径へ ルニアに対し再度 TAPPを施行した 2 例を経験したの で，若干の文献的考察を加え報告する。

\section{症例}

\section{症例 1}

患者：74 歳, 男性.

主訴：両側鼠径部膨隆.
既往歴：特記すべきことなし.

現病歴：8 か月前に両側鼠径へルニア（〔Japanese Hernia Society: 以下, JHS]のヘルニア分類で左右とも にIV 型）に対し TAPPを施行した。合併症なく経過良 好であったが，6か月前より徐々に両側鼠径部の膨隆を 認め，当院を受診した。

現症：身長 $159 \mathrm{~cm}$, 体重 $63 \mathrm{~kg}$. 立位にて両側鼠径部 に鶏卵大の膨隆を認めた。

両側再発鼠径ヘルニアと診断し再手術の方針となっ た. 患者本人は早期社会復帰の期待できる腹腔鏡下手術 を希望した。当科ではこの症例が TAPP 導入後初めての 再発例であり，鼠径部切開法と比較し留置したメッシュ の展開や収縮の状態，また再発形式を詳細に評価できる TAPP を施行することで, 今後の手術により再発させな い確実な手技をフィードバックできると考え，鼠径部切 開法の併用も念頭におき，再び TAPPを施行した。

手術所見：臍部に open 法で $12 \mathrm{~mm}$ ポートを挿入気腹 し, 左側腹部に $12 \mathrm{~mm}$ ポート, 右側腹部に $5 \mathrm{~mm}$ ポー 卜を挿入した。腹腔内には前回手術の癒着は認めなかっ た。鼠径部を観察すると, 両側とも下腹壁動静脈から外 側のメッシュの展開は良好であったが，内側に展開して いたメッシュが，鼠径管後壁にて腹腔外へ押し出される ように再発していた (Fig. 1, 2). 前回手術では腹直筋裏 


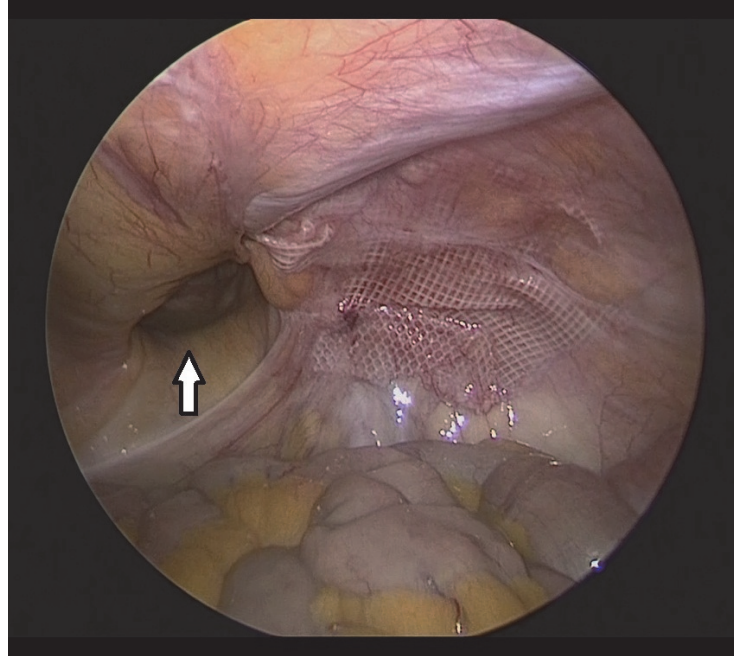

Fig. 1 Laparoscopic surgical findings

The recurrent right inguinal hernia was found (JHS type II-3) (arrow).

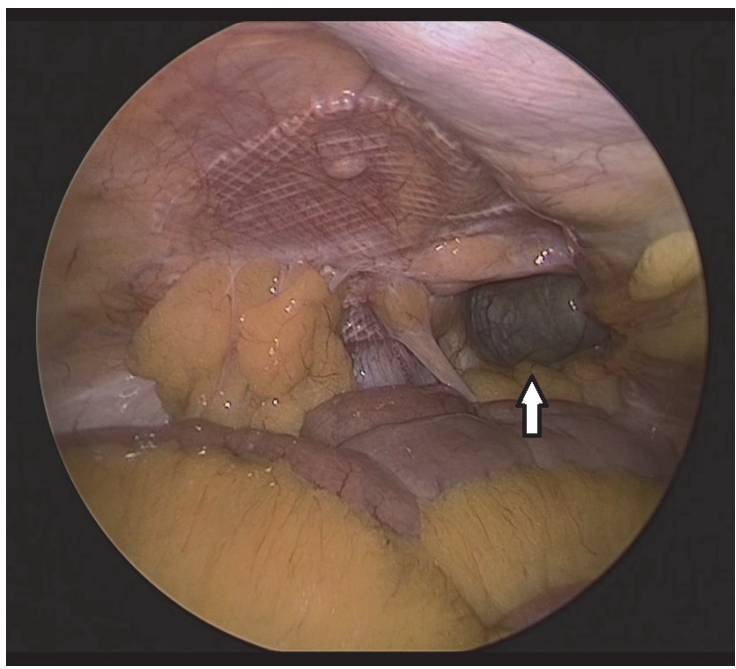

Fig. 2 Laparoscopic surgical findings

The recurrent left inguinal hernia was found (JHS type II-3) (arrow).

面正中までを覆うようにメッシュを展開しタッキングし ていたが，腹直筋竬面はメッシュで覆われていなかっ た。ヘルニア分類では II-3 型であった。メッシュの展 開されている部分は問題ないと判断し, 下腹壁動静脈よ り内側のヘルニア門周囲を十分に剥離して再びメッシュ で補強することとした，右再発鼠径へルニアより手術を 行った。ヘルニア門外側より腹膜切開し, 腹膜前腔を 丁寧に剥離した。前回手術の影響で層構造が不明瞭であ り，一部は腹膜前筋膜浅葉と横筋筋膜の間の層での剥離 となったが, 大部分で腹膜前腔の正しい層での剥離が可 能であった。ヘルニア門周囲を十分に剥離すると, ヘル ニア門は径 $3 \mathrm{~cm}$ であった。 $10 \times 7 \mathrm{~cm}$ にトリミングした Parietex ${ }^{\mathrm{TM}}$ mesh を挿入展開し, AbsorbaTack ${ }^{\mathrm{TM}}$ で腹直筋

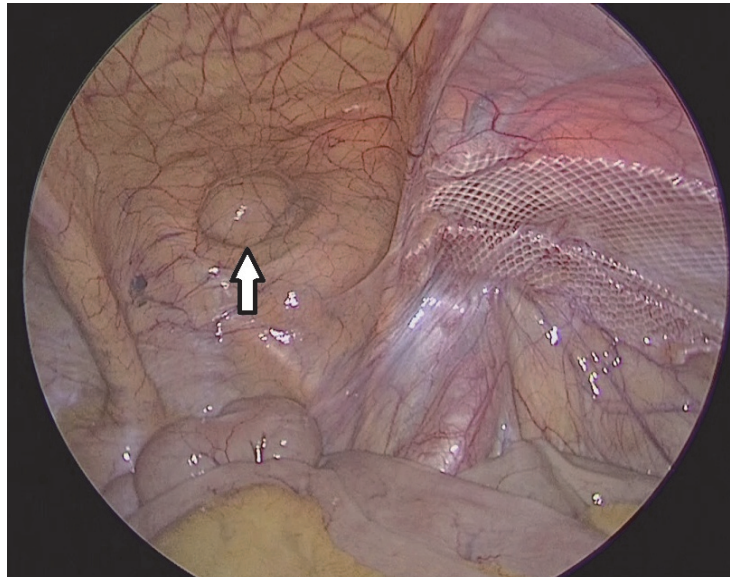

Fig. 3 Laparoscopic surgical findings

The recurrent right inguinal hernia was found (JHS type II-1) (arrow).

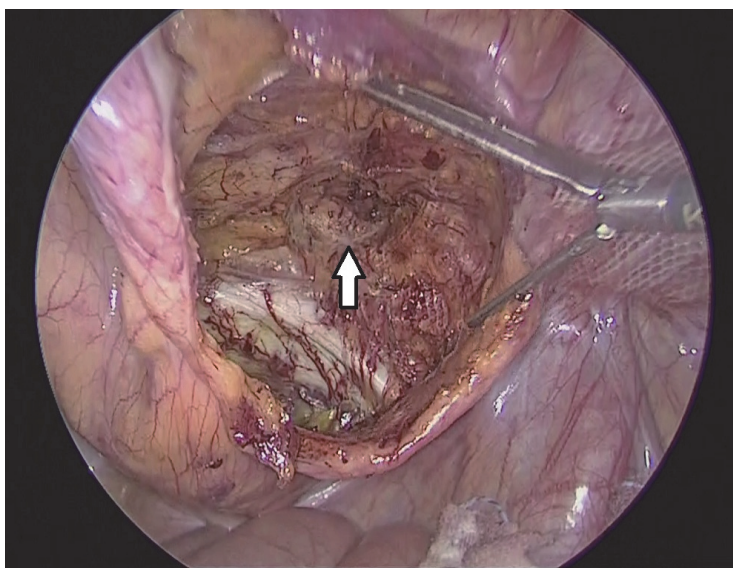

Fig. 4 Laparoscopic surgical findings

The hernia orifice was found after dissection of preperitoneal cavity (arrow).

裏面, cooper 勒带や恥骨に固定した。腹膜は吸収糸で 連続縫合した。左再発鼠径ヘルニアに対しても同様に剥 離し，径 $3 \mathrm{~cm}$ のヘルニア門を認め，9×7 cm にトリミ ングした meshを使用して修復した。手術時間は290分, 出血量は少量であった。

術後経過：合併症なく術後 2 日で退院となった。その 後 2 年間再発は認めていない.

\section{症例 2}

患者：69 歳, 男性.

主訴：右鼠径部膨隆.

既往歴：68 歳時に心筋梗塞で治療している.

現病歴： 2 年前に両側鼠径ヘルニア (JHS のヘルニア 分類で, 右：II-3 型, 左：IV 型）に対し TAPPを施行 した．合併症もなく経過良好であったが，6 か月前より 右鼠径部膨隆を認めたため当院を受診した。

現症：身長 $173 \mathrm{~cm}$, 体重 $68 \mathrm{~kg}$. 立位にて右鼠径部に 


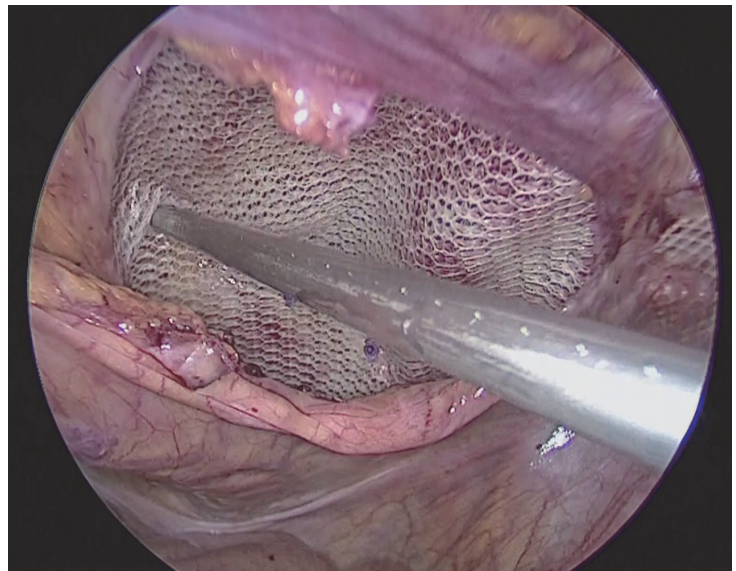

Fig. 5 Laparoscopic surgical findings

The hernia orifice was thoroughly covered with a $10 \times 10 \mathrm{~cm}$ sized mesh. The mesh was fixed with an AbsorbaTack ${ }^{\mathrm{TM}}$.

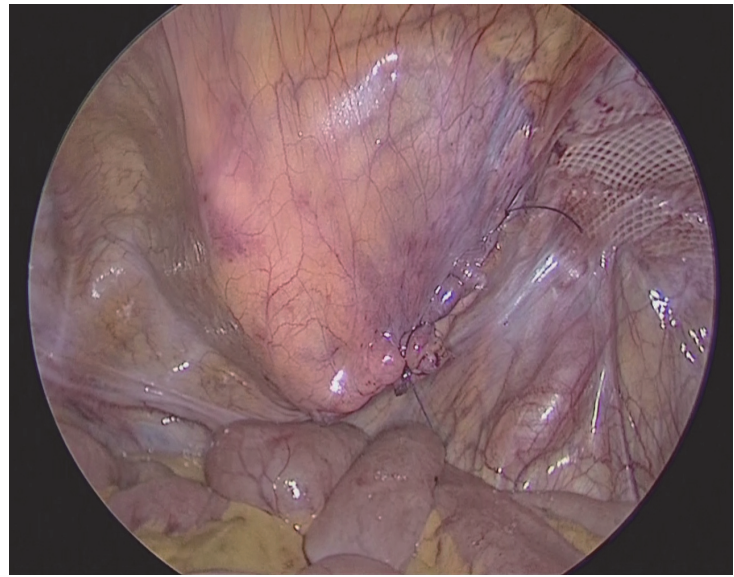

Fig. 6 Laparoscopic surgical findings The peritoneum was closed by continuous suture.

Table 1 Reported cases of laparoscopic surgery for recurrent inguinal hernia after transabdominal preperitoneal repair

\begin{tabular}{cccccccccc}
\hline No. & Year & Author & Age & Sex & $\begin{array}{c}\text { Side of } \\
\text { hernia }\end{array}$ & $\begin{array}{c}\text { Classification (JHS) } \\
\text { at first operation }\end{array}$ & $\begin{array}{c}\text { Duration from operation } \\
\text { till recurrence }\end{array}$ & $\begin{array}{c}\text { Classification (JHS) } \\
\text { at re-operation }\end{array}$ & $\begin{array}{c}\text { Size of } \\
\text { hernia orifice }\end{array}$ \\
\hline 1 & 1996 & Kasugai $^{12}$ & 72 & M & right & II & 11 months & II-1 & NS \\
2 & 1996 & Kasugai $^{12)}$ & 44 & M & left & II & 10 months & II-1 & NS \\
3 & 2009 & Kawabe $^{11)}$ & 73 & F & right & II & NS & II & NS \\
4 & 2014 & Kato $^{10}$ & 65 & M & right & II-1 & 19 months & II-1 & NS \\
5 & 2016 & case 1 & 74 & M & bilateral & IV, IV & 2 months & II-3, II-3 & $3 \mathrm{~cm}, 3 \mathrm{~cm}$ \\
6 & 2016 & case 2 & 69 & M & right & II-3 & 18 months & II-1 & $2 \mathrm{~cm}$ \\
\hline
\end{tabular}

JHS: Japanese Hernia Society, NS: not stated

鶏卵大の膨隆を認めた。

右再発鼠径ヘルニアと診断し, 患者の希望もあり, メッシュの状態や再発形式の詳細な評価を行える TAPP を再び施行した。

手術所見：症例 1 と同様に腹腔鏡下に鼠径部を観察 すると，鼠径管後壁にてメッシュが腹腔外へ押し出され るように再発しており,ヘルニア分類は II-1 型であっ た (Fig. 3).ヘルニア門周囲を十分に剥離すると、ヘル ニア門は径 $2 \mathrm{~cm}$ であり，10×10 cm にトリミングした Pariete ${ }^{\mathrm{TM}}$ mesh を挿入展開し, AbsorbaTack ${ }^{\mathrm{TM}}$ で腹直筋 裏面，cooper 勒带や䎵骨に固定した (Fig. 4, 5)。腹膜は 吸収糸で連続縫合した (Fig. 6)。手術時間は 78 分, 出血 量は少量であった。

術後経過：合併症なく術後 2 日で退院となった。その 後 1 年 5 か月間再発は認めていない.

\section{考察}

TAPP は本邦では 1991 年に松本 ${ }^{6}$ により導入され，そ の優れた診断能や，膜構造の温存をすることで術後の違 和感や疼痛の軽減が得られる優れた術式として徐々に普 及してきている。そその一方で，今後 TAPP 後の再発症例 が増える可能性もある. 再発鼠径ヘルニアに対する治療法
としては, 鼠径部切開法と比較し腹腔鏡下手術の優位性 は証明されてはいないが, 術後慢性疼痛の軽減や早期社 会復帰の面では腹腔鏡下手術を支持する報告もある7 ${ }^{7 \sim 9}$. 医学中央雑誌で 1977 年から 2016 年までを対象に, 「腹腔 鏡」,「鼠径ヘルニア」,「再発」で会議録を除き, 関連文献 も含め検索したところ, TAPP 後に再度 TAPP を施行した 詳細な症例報告は 3 編 4 症例の久であった ${ }^{12 ~ 12)}$ (Table 1). 自験例の 2 例も含め, 全例 II 型の再発形式であった。

日本ヘルニア学会が作成した「鼠径部へルニア診療ガ イドライン 2015 」13) では, 既往手術が腹膜前修復法後の 再発では鼠径部切開法が推奨されるが, 腹膜前修復法で 治療されていない場合には腹腔鏡下ヘルニア修復術は手 技に十分習熟した外科医が実施する場合に扔いて再発へ ルニアに適している（推奨グレードB）とされている. TAPP の長所としては, (1) 再発形式を腹腔内から直接視 認し把握できる, (2) 人工補強材と腹膜の癒着の程度を 認識し, 癒着の少ない部分からの剥離が可能である, (3) 拡大視効果により, 術後の複雑化した組織の解剖学的理 解を得やすくなる, (4)へルニア門周囲の必要最小限の 剥離を行うことで, 急性・慢性疼痛のリスクを軽減でき る，(5) 早期社会復帰が期待できることなどが挙げられ る。逆に TAPP の短所としては, 全身麻酔が必要である 
ことや，鼠径部切開法と比較し技術的な難易度が高く， 医療コストが高いことなどが挙げられる.

自験例の 2 例はともにヘルニア分類 II 型の再発であ り，腹直筋裏面の mesh のオーバーラップ不足や確実な タッキングができていないことなどに起因しているもの と思われた。 その後は腹直筋毫面の剥離, メッシュの十 分なオーバーラップおよび固定を意識して手術するよう になり，現在までに再発は経験していない。

再発鼠径へルニアに対する手術時期としては, 疼痛が 強い例や嵌頓例などを除き, 初回手術から 6 か月以上 経過して行うのが望ましいとされている。6 か月以内で は瘏痕組織に新生血管が多く組織の癒着も強い状態であ り，また補強されている部分とそうでない部分の鑑別も 困難である. 自験例の症例 1 では初回術後 2 か月で再発 したが，鼠径部膨隆以外の症状は認めなかったため，癒 着の強い時期であることを考慮し, 再手術の時期を初回 術後 8 か月まで遅らせて対応した.

再発鼠径へルニアに対しては様々な治療戦略がある が, 言うまでもなく初回手術で再発のない質の高い手術 を心がけるべきであり，個々の症例において最良な術式 を常に模索することが肝要である.

\section{結＼cjkstart語}

TAPP 後の再発鼠径ヘルニアに対し再度 TAPPを施行 した 2 例を経験した。TAPP は再発形式の確実な評価や 診断および修復が可能であると考えられた。

\section{文献}

1）横山隆秀，林賢．再発例に対する腹腔鏡下へ ルニア修復術。外科治療 2006; 94: 846-848.

2) 松谷毅, 宮本昌之, 柳健, 他. 再発鼠径ヘルニ
アに対する腹腔鏡下経腹的腹膜前メッシュ修復術の検 討。日臨外会誌 2009; 70: 368-374.

3) 村上慶洋, 阿部紘丈, 山本高正, 他. 再発鼠径へ ルニアに対する経腹腹腔鏡下鼠径ヘルニア根治術 (transabdominal preperitoneal repair) の検討。日鏡外会誌 2011; 16: 551-558.

4) 村上慶洋, 吉見泰典, 倉島 庸, 他. 再発鼠径へ ルニアに対する経腹腹腔鏡下鼠径ヘルニア根治術 (Transabdominal Preperitoneal Repair: TAPP) の有用性. Med Photonics 2013; 14: 33-39.

5) 北野正剛, 山下裕一, 白石憲男, 他. 内視鏡外科手術 に関するアンケート調査一第 12 回集計結果報告一. 日 鏡外会誌 2014; 19: 495-640.

6) 松本純夫. 腹腔鏡下鼠径ヘルニア手術。手術 1993; 47 645-650.

7) Karthikesalingam A, Markar SR, Holt PJ, et al. Metaanalysis of randomized controlled trials comparing laparoscopic with open mesh repair of recurrent inguinal hernia. Br J Surg 2010; 97: 4-11.

8) Dedemadi G, Sgourakis G, Radtke A, et al. Laparoscopic versus open mesh repair for recurrent inguinal hernia: a meta-analysis of outcomes. Am J Surg 2010; 200: 291-297.

9) Kouhia ST, Huttunen R, Silvasti SO, et al. Lichtenstein hernioplasty versus totally extraperitoneal laoaroscopic hernioplasty in treatment of recurrent inguinal hernia-a prospective randomized trial. Ann Surg 2009; 249: 384-387.

10）加藤恭郎, 牛丸裕貴, 鈴木大聡. TAPP 後, 腹膜陥凹の ない腹膜外型膀胱ヘルニアを発症した一例。 日ヘルニ ア会誌 2014; 1: 41-45.

11）川辺昭浩, 木村泰三, 鈴木憲次, 他. 再発鼠径ヘルニ アの治療戦略—とくにメッシュ使用後—. 消外 2009; 32: 365-375.

12）春日井尚, 山川達郎, 宇仁 淳, 他. 腹腔鏡下鼠径 ヘルニア修復術後再発例の検討。帝京医誌 1996; 19: 381-388.

13) 日本ヘルニア学会ガイドライン委員会. 鼠径部へ ルニア診療ガイドライン 2015。金原出版, 東京, 2015. 